\title{
Den norske matvaretabellen og beregningsdata- basen ved Institutt for ernæringsforskning
}

\author{
Arnhild Haga Rimestad ${ }^{1}$, Elin Bjørge Løken ${ }^{2}$ og Astrid Nordbotten ${ }^{3}$ \\ ${ }^{I}$ Statens råd for erncering og fysisk aktivitet \\ ${ }^{2}$ Institutt for ernceringsforskning, Universitetet i Oslo \\ ${ }^{3}$ Veterincerinstituttet, Oslo \\ Korrespondanse: Arnhild Haga Rimestad, Statens råd for ernæring og fysisk aktivitet, Boks 8139 Dep, 0033 Oslo \\ e-post: arnhild.rimestad@sef.no
}

\begin{abstract}
SAMMENDRAG
Opplysninger om matvarers innhold av energi og næringsstoffer er nødvendig i mange sammenhenger for overvåking av kostholdet i ulike befolkningsgrupper, for studier av sammenhenger mellom kosthold, livsstil og helse, ved veiledning, undervisning og opplysning om et helsemessig godt kosthold. De fleste vestlige land har en trykt matvaretabell som viser næringsinnholdet per $100 \mathrm{~g}$ matvare for et representativt utvalg av de vanligste matvarene. Ved næringsberegning av kostholdsundersøkelser brukes som regel spesialtilpassete beregningsdatabaser, disse har ofte ikke-publiserte data i tillegg. Kvaliteten på den beregningsdatabasen som benyttes ved bearbeiding av kostholdsundersøkelser kan ha avgjørende betydning for resultatene. Det er viktig at den databasen som benyttes blir omtalt i metodeavsnittet når arbeidet publiseres. Matvaremarkedet endres stadig, fokus rettes mot nye næringsstoffer og analysemetodene forbedres. Matvaretabellene og databasene må derfor revideres kontinuerlig. Næringsstoffinnholdet $\mathrm{i}$ matvarer varierer med sort, rase, fôring, dyrkingsbetingelser, lagring, transport, bearbeiding, oppskrifter og tilberedningsmetode. Siden mange av disse faktorene er forskjellig i forskjellige land, er det nødvendig å ha egne nasjonale matvaretabeller og databaser. For importerte matvarer kan det være forsvarlig å låne utenlandske verdier gitt at varen er av samme type, at håndteringen er lik og at næringsstoffdefinisjoner og analysemetoder er sammenlignbare. Det er viktig å fortsette det internasjonale samarbeidet med å gjøre tabellverk i ulike land sammenlignbare. Dette er en av forutsetningene for at resultatene fra kostholdsundersøkelser i ulike land kan sammenlignes.
\end{abstract}

\section{Rimestad AH, Løken EB, Nordbotten A. The Norwegian food composition table and the database for nutrient calculations at the Institute for Nutrition Research. Nor J Epidemiol 2000; 10 (1): 7-16.}

\section{ENGLISH SUMMARY}

Food composition data are needed for diet surveillance of the population, for epidemiological studies of diet, health and lifestyle relationships and for councelling, teaching and information about how to obtain a healthy diet. The current edition of the Norwegian food composition table presents data on energy and nutrient content for 882 foods. Only $23 \%$ of the table values are based on analytical work from Norwegian laboratories, $28 \%$ are calculated from recipes, $20 \%$ are borrowed from other tables, $13 \%$ are imputed from similar foods and $16 \%$ are missing. Most of the values refer to raw foods. A number of borrowed and estimated values from other sources as well as recipes for cooked foods have been added by the Institute for Nutrition Research at the University of Oslo to their database for nutrient calculations in dietary surveys. In this article we describe the procedures for sampling of foods to be analysed, how the analytical results are compiled and what factors are used to account for vitamin losses in recipe calculation. Resources for continuous revisions of the Norwegian food composition table are needed as the users focus on new food components, the analytical methods are improved and the food market as well as the dietary habits of the population change over time.

\section{OVERVÅKING AV NORSK MAT OG KOSTHOLD}

"A knowledge of the chemical composition of foods is the first essential in any study of human nutrition" (1).
Opplysninger om matvarenes innhold av energi og næringsstoffer er nødvendig for overvåking av kostholdet i befolkningen, for studier av sammenhenger mellom kosthold, livsstil og helse og ved veiledning, undervis- 
ning og opplysning om et helsemessig godt kosthold. Denne artikkelen fokuserer på arbeidet bak verdiene $\mathrm{i}$ den norske matvaretabellen og bruken av dem i forbindelse med næringsstoffberegning av kostholdsundersøkelser.

Statens råd for ernæring og fysisk aktivitet (SEF) og Statens næringsmiddeltilsyn (SNT) har siden 1991 hatt et felles ansvar for å beskrive og følge utviklingen i norsk kosthold over tid (figur 1), mens de ernæringsmessige beregningene utføres ved Institutt for ernæringsforskning, Universitetet i Oslo (IE). Kostholdet overvåkes på tre nivå, dvs. gjennom matforsyningsstatistikk, forbruksundersøkelser og individuelle kostholdsundersøkelser. Disse datakildene stiller ulike krav til beregningsdatabasen.

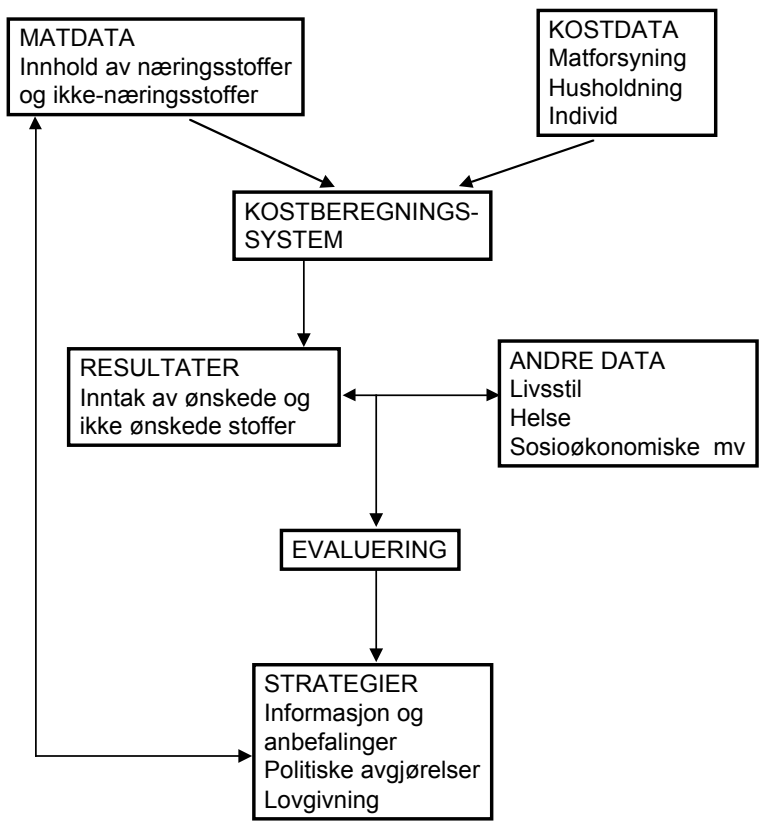

Figur 1. Overvåking av norsk mat og kosthold.

Matforsyningsstatistikken gir opplysning om hvor mye mat som står til rådighet for hele befolkningen. Statistikken er laget ut fra oppgaver over den mengde råvarer som blir produsert og brukt til menneskemat $\mathrm{i}$ Norge hvert år, pluss all innført mat og drikke, minus det som går til eksport. Til dette beregningsformålet trengs det først og fremst data om næringsinnholdet i råvarer som for eksempel mel, melk, egg, kjøtt, fisk, poteter, grønnsaker og frukt.

I forbruksundersøkelsene registrerer landsrepresentative utvalg av privathusholdninger hvert år hvor mye de kjøper eller på annen måte skaffer seg av mat og drikke i løpet av en to ukers periode. Til dette beregningsformålet trengs det ikke bare data om råvarer, men også opplysninger om industrielt fremstilte produkter som for eksempel brød, konserverte produkter av grønnsaker og frukt, farsevarer og andre produkter av kjøtt og fisk, ulike typer pålegg og drikke.

Databasekravene blir enda større når en skal beregne det virkelige inntaket av energi og næringsstoffer hos enkeltpersoner. Ved slike kostholdsundersøkelser blir inntaket registrert i den form maten blir spist, hvilket betyr at databasen også bør ha opplysninger om kokte og stekte retter slik de lages til både i privathusholdninger og i ulike typer institusjoner, gatekjøkken og andre serveringssteder. Ikke bare formålet med undersøkelsen, men også svarernes evne til å beskrive hva de har spist, avgjør hvor detaljerte opplysninger en trenger ved næringsstoffberegningen. Kliniske ernæringsfysiologer vil for eksempel ønske opplysninger om så spesifikke matvarer som mulig. Til næringsstoffberegning av de spørreskjemaene IE har utviklet for å kartlegge kostholdet til deltakerne i Norkost- og Ungkostundersøkelsene (2-4) trengs på den annen side representative verdier for en del aggregerte matvarer og retter. Et slikt aggregat kan for eksempel være "kjøttpålegg". Ideelt sett bør forholdet mellom de varene aggregatkoden omfatter svare til bruksmønsteret i den gruppen som undersøkelsen omfatter.

Som vist i figur 2 er det mange faktorer som har betydning for utfallet av en næringsstoffberegning. $\AA$ ha representative verdier for matvarenes innhold av næringsstoffer er like viktig som å ha gode data for matinntak, men det er som regel bare faktorene i nedre del av figuren som blir omtalt når resultatene presenteres.

"A food composition data base or table is a scientific tool and must be treated as such. The compilers are responsible for ensuring that the data base meets the user's requirements and they must also define for the user the limitations of the data base, so that the data are not used inappropriately. However, correct use is the responsibility of those who train the users, and of the users themselves." (1).

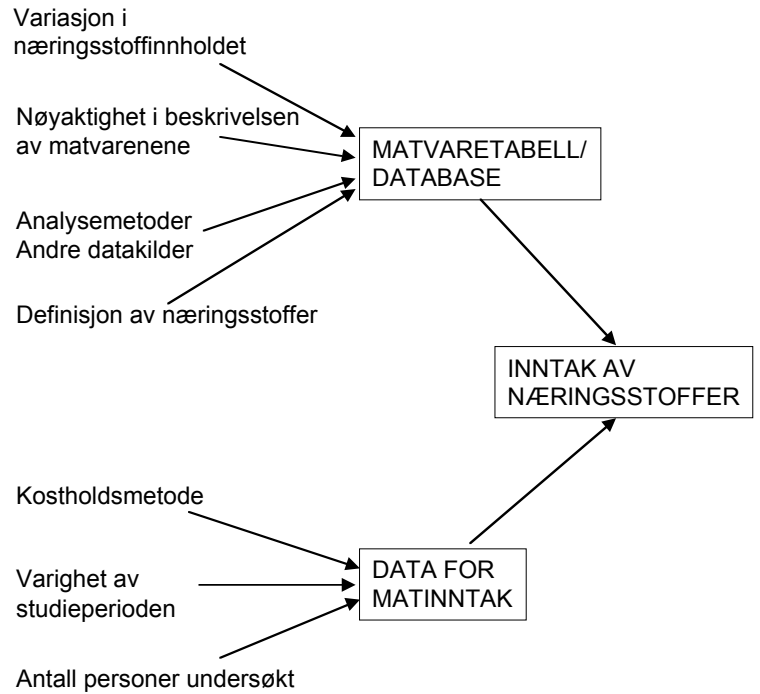

Figur 2. Faktorer som påvirker resultateter av næringsstoffberegninger. 


\section{DEN NORSKE MATVARETABELLEN}

"There are two schools of thought about food tables. One tends to regard the figures in them as having the accuracy of atomic weight determinations; the other dismisses them as valueless on the ground that a foodstuff may be so modified by soil, the season or its rate of growth that no figure can be a reliable guide to its composition. The truth, of course, lies somewhere between these two points of view" (1).

Den første norske matvaretabellen ble utgitt i 1958 (5) som følge av at kostholdsforskere noen år tidligere hadde satt i gang undersøkelser av kostholdet i storhusholdninger og blant grupper av befolkningen. Den trykte tabellen er senere revidert seks ganger. Siste utgave ble utgitt både som skoletabell (6) og en noe større tabell (7).

"Den store matvaretabellen 1995" har verdier for innhold av energi, inntil 33 næringsstoffer og tre fettsyresummer per $100 \mathrm{~g}$ spiselig del i 882 matvarer. For halvparten av matvarene finnes det også verdier for 18 enkeltfettsyrer. Selv om det til denne tabellutgaven ble analysert råvarer og industriprodukter for ca. 8 millioner kroner, utgjør analyseverdiene fremdeles ikke mer enn $23 \%$ av dataene i tabellen. Resten er lånt fra andre lands tabeller $(20 \%)$, estimert i forhold til liknende matvarer $(13 \%)$, beregnet ut fra resept (28\%) eller er ukjent $(16 \%)$. De aller fleste verdiene gjelder råvarer og industriprodukter, bare noen få tillagete matvarer og retter er med i denne utgaven av tabellen.

\section{Analysedata}

Til 1995-utgaven av matvaretabellen ble det først og fremst prioritert å skaffe nye analyseverdier for norskproduserte råvarer som poteter, grønnsaker, frukt og bær, mel, kjøtt, melk og melkeprodukter. Samtidig ble utvalget av næringsstoffer økt med blant annet magnesium, kopper, sink, selen og flere B-vitaminer.

Råvarene er av biologisk opprinnelse og næringsinnholdet vil kunne variere med plantesort eller dyreart så vel som forholdene under vekst, høsting eller slakting, videreforedling og oppbevaring, se tabell 1 . Ved utarbeidelse av prøvetakingsplaner er det derfor viktig å ta høyde for de forholdene som kan variere slik at utvalget blir mest mulig representativt.

For å få kunnskap om hvor stor variasjonen kunne være ble det prioritert å analysere enkeltprøver av matvarer som var særlig viktige i norsk kosthold og de næringsstoffene som disse matvarene var betydelige kilder for. De fleste matvarene ble imidlertid analysert som samleprøver, først og fremst av ressursmessige grunner, men også fordi tabellbrukeren som regel ikke kjenner opprinnelsen til de matvarene som skal næringsberegnes. Opplysninger om variasjonen går da tapt. Vanligvis blir det heller ikke prioritert å analysere for stoffer i matvarene som disse ikke er en kilde for $\mathrm{i}$ norsk kosthold. For eksempel blir det ikke analysert for vitamin D og kolesterol i mel siden disse stoffene ikke finnes i korn. I slike tilfeller blir tabellverdien satt til "0", en såkalt naturlig null.

I USA er det utarbeidet forslag til hvordan analyseverdier kan kvalitetsgraderes $(1,8)$. Dette er forsøkt gjort for kostfiber i en brasiliansk matvaretabell som finnes på internett (9). Bare $12 \%$ av verdiene deres fylte kravet til høyeste eller nest høyeste kvalitet (10). I den norske matvaretabellen vil anslagsvis $15 \%$ kunne oppnå høyeste eller nest høyeste kvalitetskode.

\section{Eksempel 1: Vitamin C i potet}

I 1992-95 ble det foretatt en rekke undersøkelser av næringsstoffinnholdet i norskproduserte friske plantematvarer. Gangen i arbeidet fra planlegging av prøveuttak til verdi i matvaretabellen er illustrert i det følgende for vitamin $\mathrm{C}$ i potet (11).

I følge Markedskontoret for poteter dyrkes det her i landet tre hovedsorter av tidligpoteter, to hovedsorter med høstpoteter og tre sorter lagringspoteter. Tabell 2 viser at nesten tre firedeler av all matpotet blir dyrket på Østlandet. Prøveuttakingsplanen ble derfor basert på omfanget av de viktigste potetsortene $\mathrm{i}$ hvert dyrkingsområde. Innen de enkelte områdene ble det tatt delprøver fra fem ulike produsenter, disse ble av ressursmessige årsaker slått sammen til samleprøver.

Tabell 1. Forhold som påvirker matvarenes innhold av næringsstoffer.

\begin{tabular}{lll}
\hline Vegetabilske råvarer & Animalske råvarer & Bearbeidede varer \\
\hline Definisjon av spiselig del & Definisjon av spiselig del & \\
Jordsmonn & Fôr & Råvarenes sammensetning \\
Klima & Beite & \\
Gjødsling & Kraftfôr & Oppskrifter \\
Planteforedling & Avl & Bearbeidingsmetoder \\
Modenhetsgrad ved høsting & Slaktealder & \\
Utmalingsgrad & Stykking av slakt & \\
Beriking & Beriking & Beriking \\
Lagring og transport & Lagring og transport & Lagring og transport \\
Tilberedning & Tilberedning & Tilberedning \\
\hline
\end{tabular}


Tabell 2. Sorter av matpoteter fordelt på dyrkingsområdene.

\begin{tabular}{lccccc}
\hline & & \multicolumn{5}{c}{ Dyrkingsregion } \\
\cline { 3 - 6 } $\begin{array}{l}\text { Potetslag } \\
\text { (hovedtypene) }\end{array}$ & $\begin{array}{c}\text { Norge } \\
\%^{1}\end{array}$ & $\begin{array}{c}\text { Østlandet } \\
\%^{2}\end{array}$ & $\begin{array}{c}\text { Rogaland } \\
\%^{2}\end{array}$ & $\begin{array}{c}\text { Trøndelag } \\
\%^{2}\end{array}$ & $\begin{array}{c}\text { Nord-Norge } \\
\%^{2}\end{array}$ \\
\hline $\begin{array}{l}\text { Tidligpoteter } \\
\quad \text { Rutt }\end{array}$ & 3 & 61 & 8 & 10 & 0,3 \\
$\quad$ Ostara & 2 & 49 & 21 & 21 & 0,3 \\
$\quad$ Snøgg & 2 & 69 & 13 & 6 & 0,9 \\
Høstpoteter & & & & & \\
$\quad$ Laila & 4 & 76 & 6 & 13 & 0,1 \\
$\quad$ Troll & 18 & 18 & 21 & 35 \\
Lagringspoteter & & & & & \\
$\quad$ Beate & 34 & 91 & 3 & 3 & 0,1 \\
$\quad$ Pimpernell & 14 & 45 & 9 & 35 & 5,5 \\
$\quad$ Kerrs Pink & 4 & 72 & 19 & 6 & 0,1 \\
\hline
\end{tabular}

${ }^{1}$ Arealprosent, alle sorter matpotet dyrket i Norge. Andre typer matpoteter $(8 \%)$ og sorter som kun brukes til chipsproduksjon o.l. (20\%) kommer i tillegg.

${ }^{2}$ Regionvis arealprosent for hver hovedsort.

Prøvene ble vasket, skrelt, homogenisert, fryselagret og analysert med en fluorometrisk metode etter nøye oppsatt prosedyre. Resultatet viste at innholdet av vitamin $\mathrm{C}$ varierte mellom $7 \mathrm{og} 20 \mathrm{mg}$ per $100 \mathrm{~g}$ rå potet. Den laveste verdien ble funnet $\mathrm{i}$ lagringspoteter som hadde blitt oppbevart fram til mai neste år, mens den høyeste verdien gjaldt tidligpoteter dyrket på Østlandet.

Tabellverdiene for innhold av vitamin $\mathrm{C}$ i tidligpoteter, høstpoteter og lagringspoteter er beregnet ut fra analyseresultater gjengitt i tabell 3 og formler (appendix 1) for beregning av veide gjennomsnitt $\mathrm{i}$ forhold til markedsandeler for de ulike sortene og dyrkingsområdene.

Sammenliknet med forrige utgave av matvaretabellen (12) er innholdet av vitamin C i lagringspoteter nå blitt $60 \%$ høyere. Dersom den tidligere tabellverdien var blitt brukt ved beregning av Norkost (2) ville inntaket av vitamin $\mathrm{C}$ blitt 6-7 \% lavere.

Både nåværende og tidligere verdi for vitamin $\mathrm{C} \mathrm{i}$ rå lagringspoteter er innenfor området av verdier som brukes i de øvrige landene i Norden. Den danske matvaretabellen oppgir 27 mg (13), mens både svensk og finsk tabell viser $11 \mathrm{mg}$ vitamin $\mathrm{C}$ per $100 \mathrm{~g}$ rå potet (14-15). Ulike sorter og vekstbetingelser kan sannsynligvis forklare noe av forskjellene, men de kan også være kunstige som følge av ulike utvalgs- og analysemetoder.

\section{Eksempel 2: Selen i matmel, kjøtt og melk}

Matmelets innhold av selen er avhengig av selenkonsentrasjonen i jorda der kornet dyrkes. I norsk åkerjord er det lite selen, mens en stor del av det importerte kornet kommer fra områder med mer selenholdig jord. Så lenge Statens kornforretning hadde enerett både på å kjøpe norskprodusert korn og å im- portere korn ble sortene blandet slik at vi fikk mel med høyt innhold av selen og gode bakeegenskaper. Som følge av EØS-avtalen måtte imidlertid det norske melmonopolet opphøre.

Både møllene og de store bakeriene kan nå importere korn og mel selv, noe som gjør at næringsinnholdet varierer mer enn tidligere. De senere årene har norskprodusert korn i matmelet økt betydelig, i løpet av 1990-årene har andelen variert mellom 30 og $50 \%$. Beregninger foretatt i 1983 viste et totalt inntak på 86 $\mu \mathrm{g}$ selen per dag (16), dette har ifølge interne beregninger nå falt til ca. $65 \mu \mathrm{g}$. Det har vært forsøkt å tilsette selen til kalksalpeter, men produksjonen har stoppet da bruken av dette gjødslet var begrenset (Norsk institutt for landbruksøkonomisk forskning, personlig meddelelse).

Kraftfor har vært tilsatt selen siden 1979 av hensyn til optimal dyrehelse. Dette har gitt høyere innhold av selen i både kjøtt og melk.

\section{Variasjon}

Tabell 4 viser eksempler på variasjonsbredde for enkelte matvarers innhold av folat. I neste utgave av matvaretabellen vil vi ta med data om variasjon for flere matvarer og næringsstoffer for å minne brukerne på at de veide tabellverdiene alltid må oppfattes som nivå og at variasjonen kan være betydelig.

\section{Beregnete naeringsstoffverdier}

Innholdet av protein har tradisjonelt blitt beregnet på grunnlag av matvarenes innhold av total-nitrogen ved å multiplisere den analyserte nitrogenmengden med matvareavhengige proteinfaktorer. I den norske matvaretabellen brukes faktoren 5,70 for mel og brødvarer, 6,38 for ost og 6,25 for øvrige matvarer. I enkelte 
Tabell 3. Innhold av vitamin $\mathrm{C}$ i ulike potetsorter etter dyrkingsområde og veid snitt for landet totalt $(\mathrm{mg} / 100 \mathrm{~g}$ rå spiselig del).

\begin{tabular}{|c|c|c|c|c|c|}
\hline \multirow[b]{2}{*}{ Potetsort } & \multicolumn{4}{|c|}{ Dyrkingsområde } & \multirow{2}{*}{$\begin{array}{l}\text { Landet totalt } \\
\text { Veid snitt }\end{array}$} \\
\hline & Østlandet & Rogaland & Trøndelag & Nord-Norge & \\
\hline Tidligpoteter 1993 & & & & & $17^{1}$ \\
\hline Rutt & 15,7 & 20,1 & 11,4 & & 16 \\
\hline Ostara & 18,7 & 17,2 & 8,4 & & 16 \\
\hline Snøgg & 19,7 & 18,6 & 11,5 & & 19 \\
\hline Høstpoteter 1993 & & & & & $13^{1}$ \\
\hline Laila & 14,1 & & & & 14 \\
\hline Troll & & & & 9,4 & 9 \\
\hline Lagringspoteter 1993 & & & & & $16^{1}$ \\
\hline Beate & 15,8 & 15,0 & 18,7 & & 16 \\
\hline Pimpernell & 13,7 & 12,5 & 17,5 & & 15 \\
\hline Kerrs Pink & 16,3 & 15,9 & 15,4 & & 16 \\
\hline
\end{tabular}

${ }^{1}$ Vitamin C innhold gitt i matvaretabellen $1995(6,7)$.

Tabell 4. Eksempler på variasjon (minimums- og maksimumsverdier) $\mathrm{i}$ innhold av folat.

\begin{tabular}{lcc}
\hline Matvare & $\begin{array}{c}\text { Antall } \\
\text { prøver }\end{array}$ & $\begin{array}{c}\text { Variasjonsområde }^{1} \\
\square g / 100 \text { g spiselig matvare }\end{array}$ \\
\hline Lagringspotet & 11 & $5,5-17,2$ \\
Leverpostei & 3 & $87-200$ \\
Egg & 45 & $49-103$ \\
\hline
\end{tabular}

${ }^{1}$ Nye data som skal inn i neste utgave av matvaretabellen.

land blir det brukt mer detaljerte faktorer for en del matvarer (17), mens andre land bruker faktoren 6,25 for alle matvarer.

Av ressursmessige grunner er fettsyreinnholdet i ulike typer melk, melkeprodukter og rått kjøtt beregnet i forhold til totalt fettinnhold og analyseverdier for fettsyresammensetningen i noen få typiske prøver. Med tradisjonelle analysemetoder for bestemmelse av totalfett får en også med innholdet av glyserol, fosfolipider og kolesterol. Disse komponentene utgjør mellom 5 og $30 \%$ av totalfettet. Fra finsk hold er det derfor foreslått at total mengde fett bør defineres som summen av fettsyrer (18).

Mange vitaminer opptrer i ulike former i matvarene, disse kan ha forskjellig vitaminaktivitet eller biotilgjengelighet. For noen vitaminer har det vært vanlig å lage et samlet mål for aktiviteten ved å beregne såkalte ekvivalenter, dette er først og fremst gjort for vitamin A og niacin i den norske matvaretabellen (se foran i tabellen). I det senere har det vist seg at den tradisjonelle formelen for omregning av beta-karoten og eventuelt andre karotenoider med pro-vitamin A aktivitet til retinolekvivalenter sannsynligvis er for enkel. I enkelte planter er innholdet av beta-karoten langt dårligere tilgjengelig enn tidligere antatt, en rekke andre faktorer ved plantens tilstand, hva den spises sammen med og ernæringsstatus hos den som spiser har vist seg å ha større betydning enn tidligere antatt (19).

\section{Beregning av oppskrifter}

Næringsinnholdet i de fleste sammensatte matvarer som brød, kaker og mange industriprodukter er beregnet ut fra oppskrift. Resepter for industriprodukter er som regel konfidensielle, og i mange tilfeller har industrien brukt spesielle ingredienser der næringsinnholdet ikke har vært kjent i detalj. Endringer i innhold av vann, fett, salt samt tap av vitaminer og/eller mineraler i forbindelse med produksjon i næringsmiddelbedrift, ved tillaging i storhusholdning eller privathusholdning kan ha stor betydning for det ferdige produktets ernæringsmessige sammensetning. I matvaretabellen beskrives hvilke endringsfaktorer som er brukt.

Det er viktig å være klar over at flesteparten av de publiserte næringsstoffverdiene i 1995-utgaven gjelder matvaren i den form vi kjøper den i butikken. Steking vil for eksempel kunne medføre opptak av 0-15 g stekefett per $100 \mathrm{~g}$ ustekt vare avhengig av hvor mye fett som has i pannen, hvor porøs overflaten eller eventuelt paneringen er, og hvor lenge maten blir liggende $\mathrm{i}$ fettet. Dersom bruk av konsentrerte tilsetninger som stekefett, salt, sukker eller liknende ikke kommer med ved næringsstoffberegningen kan resultatet bli misvisende. På den annen side vil for eksempel sprøstekt og vel avrent bacon eller grillkylling spist uten skinn medføre et vesentlig lavere inntak av fett enn hva tabellverdiene viser.

\section{Verdier fra andre kilder}

\section{Låneverdier}

For flesteparten av de importerte matvarene er det lånt verdier fra utenlandske matvaretabeller, i første rekke fra de andre nordiske landene (13-15). En slik praksis kan forsvares ut fra økende internasjonalisering av matvaremarkedet. Låning forutsetter imidlertid at matvarenavnet inneholder tilstrekkelig informasjon om matvaren til at en kan avgjøre om den virkelig representerer den typen som finnes i vårt land. Definisjon 
av spiselig del kan variere og vil kunne få betydning dersom næringsinnholdet varierer med hvilken del av matvaren som blir spist. Eksempler på dette er utmalingsgrad fra korn til mel og bruk av hvite og grønne deler på purre og enkelte andre grønnsaker. En må også vite om de utenlandske matvarene er beriket med ett eller flere næringsstoffer.

Hvordan næringsstoffene er definert og angitt må være skikkelig dokumentert. Dette er imidlertid ikke alltid tilfelle. I forbindelse med EPIC-studien, en europeisk multisenterstudie om kostholdets betydning for utvikling av kreft, ble det for eksempel funnet en rekke forskjeller mellom landene med hensyn til hvordan de næringsstoffene de ville undersøke betydningen av var definert og analysert (20). Matvarenes innhold av protein, karbohydrat, karoten, vitamin A og vitamin E var ikke umiddelbart sammenliknbare. Disse forskjellene kunne imidlertid korrigeres med forholdsvis enkle omregninger. Forskjellene med hensyn til definisjon og analysemetoder for kostfiber og B-vitaminet folat var imidlertid så store at det ikke ville være mulig å sammenlikne beregningsresultatene.

Selv om en stadig økende del av den maten som blir spist i Norge er av utenlandsk opprinnelse, har mange norskproduserte matvarer likevel en såpass spesiell sammensetning at det er nødvendig å ha en nasjonal matvaretabell. Årsaken kan være ulike plantesorter, dyreraser, forhold under produksjon av råvaren, industriell bearbeiding eller ulike regler for beriking med næringsstoffer. Tabell 5 viser eksempler på råvarer som kan ha ulik sammensetning i noen land uten at dette går fram av navnet.

\section{Estimerte verdier}

For noen av matvarene i den norske matvaretabellen er det brukt estimerte verdier, det vil si at det er brukt verdier for varer som likner. Dette gjelder blant annet noen typer pasta og enkelte kjøttstykker.

\section{Verdireferanser}

I 1995-utgaven av matvaretabellen er det gitt referanse for hver enkelt verdi, noe som gir brukeren økt innsikt i hvor tallene kommer fra.

Tabell 5. Innhold av enkelte næringsstoffer i $100 \mathrm{~g}$ siktet hvetemel, potet og smør i følge verdier i amerikansk, engelsk, dansk, svensk og norsk matvaretabell.

\begin{tabular}{lccccc}
\hline & USA & England & Danmark & Sverige & Norge \\
$(22)$ & $(13)$ & $(14)$ & $(7)$ \\
Referanse & $(21)$ & $(22)$ & & & \\
\hline Hvetemel, fint & & & & 3,5 & 2,9 \\
$\quad$ kostfiber, g & 2,7 & $3,6^{2} ; 3,1^{3}$ & 3,7 & 1 & 1,5 \\
$\quad$ jern, mg & $4,64^{1}$ & 2,0 & 1,2 & & \\
Smør & & & & & \\
$\quad$ Na, mg & 826 & 750 & 562 & 470 & 593 \\
$\quad$ vit D, $\square \mathrm{g}$ & & 0,76 & 0,72 & 0,7 & $9,1^{1}$ \\
Potet & & & & & \\
$\quad$ kostfiber, g & 1,6 & $1,6^{2} 1,3^{3}$ & 1,5 & 1,4 & $2,0^{4}$ \\
$\quad$ vit C, mg & 20 & 11 & 27 & 11 & 16 \\
\hline
\end{tabular}

$\overline{{ }^{1} \text { Beriket }{ }^{2} \text { Southgate metode }{ }^{3} \text { Englyst metode }{ }^{4} \text { AOAC metode }}$

\section{Beregning av energi fra fett og karbohydrat}

I 1995-utgaven av den norske matvaretabellen ble reglene for energiberegning endret på to punkter som følge av nye EU/EØS regler om næringsdeklarering. Energiverdien per gram fett ble endret fra 38 til $37 \mathrm{~kJ}$ og kostfiber ble ikke lenger regnet for å være energigivende. Dette førte også til at innholdet av kostfiber ble trukket fra verdien for karbohydrat totalt. Siden ikke alle land har gjennomført disse endringene må en være ekstra oppmerksom ved eventuell bruk av verdier fra andre matvaretabeller.

Endringene medførte et brudd i serien av resultater fra de årlige forbruksundersøkelsene som SEF bruker i overvåkingen av det norske kostholdet (23). Med den nye regnemetoden ble innholdet av energi i gjennomsnittshusholdningens kost ca. 0,5 MJ lavere per dag $\mathrm{i}$ 1995, mens fettets andel av energien steg fra 34 til $35 \%$. Ved publisering av kostholdsdata er det derfor viktig å dokumentere hvilken utgave av matvaretabellen som er lagt til grunn for beregningene.

\section{FINANSIERING OG ORGANISERING AV ARBEIDET}

Analyse av næringsstoffinnhold i matvarer er kostbart. Med det antall næringsstoffer tabellen har i dag, kan vi få analysert ca. 40 matvarer for 1 million kroner. Dette er et minimumsnivå analyseaktiviteten bør ligge på per år for at tabellen skal kunne være forsvarlig og aktuell til enhver tid.

I perioden 1992-95 ble det gjort en ekstra stor innsats for å skaffe nye analyseverdier for norske råvarer og meieriprodukter og alle aktuelle næringsstoffer. De siste årene har det vært vanskeligere å stimulere matvareindustrien til å finansiere analyser av sine produkter. I dagens konkurransesituasjon blir nok ikke næringsstoffanalyser prioritert av matvareindustrien før det tvinger seg fram som et forbrukerkrav.

SEF og SNT har ansvar for å planlegge og gjennomføre analyseprosjektene samt revidere og utgi matvaretabellen. Arbeidet utføres i nært samarbeid med IE.

\section{Behov for kontinuerlig revisjon av matvaretabellen}

En matvaretabell blir aldri komplett. Råvarenes innhold av næringsstoffer kan endres som følge av planteforedlingsarbeid og avl. "Functional foods", det vil si mat med vitenskapelig dokumenterte tilleggsegenskaper i forhold til opprinnelig vare, er på vei inn på markedet sammen med en økende strøm av norske og etniske ferdigretter. Og når folk inntar flere måltider utenfor hjemmet (24) blir det behov for å vite sammensetning av og næringsinnhold i kantine-, gatekjøkken-, kafe- og restaurantmat.

Innen klinisk og ernæringsepidemiologisk forskning rettes fokus mot stadig nye stoffer i matvarene som for eksempel transfettsyrer, flavonoider, plantesteroler, vitamin K, ulike karotenoider, jod og krom. 
Disse bør inkluderes i framtidige matvaretabeller og beregningsdatabaser.

\section{BEREGNINGSDATABASEN VED INSTITUTT FOR ERNARINGSFORSKNING}

Ved IE blir alle kostholdsundersøkelser beregnet med et selvutviklet kostberegningssystem (Beregn). Dagens beregningsdatabase (IE96) bygger på 1995-utgaven av den norske matvaretabellen, men er utvidet med lånte, beregnete eller estimerte verdier for til sammen noe over 2000 råvarer, industriprodukter og hjemmelagete retter. Fordi mange av de nye næringsstoffene i 1995 utgaven av matvaretabellen manglet verdier for en rekke matvarer er antall regnbare næringsstoffer i IEs beregningsdatabase redusert til 20. Blant stoffer som for tiden ikke er regnbare kan nevnes stivelse, monoog disakkarider, enkeltfettsyrer, folat, natrium og flere sporstoffer.

En økende bruk av vitamin- og kosttilskudd gjør kostberegninger mer komplisert fordi ulike preparater har meget forskjellig innhold av ulike stoffer, og brukerne er ikke alltid like bevisste på hva de har spist eller pleier å spise av slike tilskudd. I mangel av analyseverdier har IE lagt inn deklarerte verdier for ca. 50 vitamin/mineralpreparater og enkelte andre kosttilskudd i sin beregningsdatabase. Næringsstoffberegningene kan derfor utføres med eller uten bidrag fra kosttilskudd.

Det arbeides kontinuerlig med å oppdatere beregningsdatabasen for å kunne ivareta næringsstoffberegninger i kostholdsundersøkelser med ulike formål. Databasen blir revidert og lagret som ny versjon når ny utgave av matvaretabellen utgis.

\section{Beregningsfaktorer for tap av vitaminer ved varme- behandling}

En internasjonal sammenstilling av studier av vitamintap ved husholdningsmessig tillaging viser store forskjeller avhengig av type matvare og vitamin, i tillegg spiller en rekke forhold ved tillagingsmetoden også inn
(25). Ved bruk av IE96-basen kan innholdet av retinol, beta-karoten, alfa-tokoferol, tiamin, riboflavin og vitamin $\mathrm{C}$ nå beregnes både med og uten fradrag for estimerte tap under husholdningsmessig tillaging. Tabell 6 viser de beregningsfaktorene som brukes. De fleste er basert på middelverdiene $\mathrm{i}$ den internasjonale rapporten, noen få stammer fra upubliserte norske forsøk.

Korrigering for tap under husholdningsmessig tillaging gir ikke særlig store utslag i vanlig norsk kost. For gjennomsnittspersonen i Norkost-undersøkelsen (2) vil for eksempel inntaket av vitamin $\mathrm{C}$ og tiamin bli redusert med $12 \%$, mens inntaket av de øvrige vitaminene bare blir 1-3\% lavere.

\section{STATUS FOR TO AKTUELLE STOFFGRUPPER}

\section{Folat}

Oppmerksomheten rundt B-vitaminet folat har økt mye de senere årene. At det er sammenheng mellom lavt inntak av folat og risiko for visse fosterskader synes å være vel dokumentert, mens en mulig sammenheng med hjerte-karsykdom, visse typer kreft og enkelte andre sykdommer ennå ikke er bekreftet i randomiserte forsøk (26).

Siden 1995-utgaven av den offisielle matvaretabellen hadde verdier for folat (i tabellen kalt folacin) ble det straks et stort press om å kunne beregne kostens innhold av folat i ulike befolkningsgrupper. Et forsøk på å beregne folatinntaket hos voksne viste et gjennomsnittlig daglig inntak på noe over $200 \mu \mathrm{g}$ for menn og noe under $200 \mu \mathrm{g}$ for kvinner, mens inntaket ble $50 \%$ høyere når gjennomsnittskosten ble beregnet med danske tabellverdier (26).

Folataktiviteten i matvarer kommer fra en rekke reduserte former av pteroylglutaminsyre (folsyre), flere av disse er svært følsomme overfor miljøpåvirkninger som tilgang på oksygen, lys, $\mathrm{pH}$ og temperatur. De første norske folatanalysene ble utført før sertifisert referansemateriale var blitt tilgjengelig og mange av låneverdiene har senere vist seg å være av varierende

Tabell 6. Estimert tap av enkelte vitaminer etter husholdningsmessig tillaging (\%) ${ }^{1}$.

\begin{tabular}{|c|c|c|c|c|c|c|}
\hline & Retinol & Beta-karoten & Alfa-tokoferol & Tiamin & Riboflavin & Vitamin $\mathrm{C}$ \\
\hline Mel i brød, kaker mv. & $(10)^{2}$ & (10) & 0 & 20 & 10 & $(35)$ \\
\hline Potet, kokt, stekt, i retter & (10) & (10) & 0 & 25 & 20 & 35 \\
\hline Grønnsaker, kokte i retter & 10 & 10 & 0 & 25 & 20 & 35 \\
\hline Syltetøy/kompott/saft & $(10)$ & 10 & 0 & 25 & 20 & 25 \\
\hline Bær, fryst & & & & & & 25 \\
\hline Kjøtt & 15 & & 20 & 40 & 10 & 25 \\
\hline Fisk & 10 & & 0 & 25 & 20 & $(35)$ \\
\hline Melk, kokt, i retter & 10 & 10 & 20 & 25 & 20 & 35 \\
\hline Egg kokt, stekt, i retter & 10 & 10 & 0 & 25 & 20 & \\
\hline Margarin/smør stekt, i retter & 10 & & 5 & & & \\
\hline
\end{tabular}

${ }^{1}$ Hovedkilde: Tabell 1 i Nutrient losses and gains in the preparation of food (25).

${ }^{2}$ Data er ikke gitt i den norske matvaretabellen (7). 
kvalitet. At forskjellige matvaretabeller kan vise svært ulike verdier for samme type matvare kan delvis forklares med stor variasjon mellom ulike sorter, men det kan og skyldes bruk av ulike analysemetoder. Det arbeides nå intenst med å skaffe flere og bedre tabellverdier for folat både i Norge og i en rekke andre land.

\section{Fettsyreinnholdet i margarin}

Harde margarintyper har ikke bare hatt et høyt innhold av mettet fett, også innholdet av såkalt transfett har vært høyt. Norske forsøk om virkningene av inntak av transfettsyrer (27) har ført til at margarinindustrien de senere årene har satset bevisst på å bedre fettsyresammensetningen i noen av de mest solgte margarintypene. Produktutviklingen startet i 1995 og norsk margarin er i dag helt fri for transfettsyrer (Kerstin Trygg, personlig meddelelse). Fram til medio 1999 har forholdet mellom mettete og umettete fettsyrer i margarin svingt så mye at det er umulig å foreta pålitelige beregninger over fettsyreinnholdet i de kostholdsundersøkelsene som er utført i denne perioden.

\section{INTERNASJONALT SAMARBEID}

Formelt internasjonalt samarbeid om matvaretabeller og databaser innen Norden, Europa og på verdensbasis har vært i gang siden begynnelsen på 1980-årene.

NORFOODS er et samarbeid mellom de statlige institusjonene i Norden som har ansvar for produksjon og utgivelse av matvaretabelldata og næringsstoffberegning av landsrepresentative kostholdsundersøkelser. Formålet med dette arbeidet er å få mest mulig sammenliknbare data (28).

Det tilsvarende europeiske samarbeidet EUROFOODS - ENFANT, senere COST 99, har som mål å harmonisere arbeidet med matvaretabeller innen Europa. I tillegg til spesielle utredninger om blant annet kodesystem for matvarer og utveksling av data på EDB, diskusjoner om analysemetodikk og omregningsfaktorer for spesielle kostkomponenter har tema som bearbeiding av engrosstatistikk, forbruksundersøkelser på husholdningsnivå og kostholdsundersøkelser på individnivå også vært behandlet. I regi av det europeiske samarbeidet er det dessuten etablert et tre ukers kurs «Graduate course on production and use of food composition data in nutrition» ved det nederlandske landbruksuniversitetet i Wageningen.
TRANSFAIR er et EU-finansiert samarbeidsprosjekt som ble gjennomført i 1995-1999. I 1995 fantes det få data om transfettsyreinnholdet i matvarer i Europa. De data som fantes var av ulik kvalitet og til dels framkommet med bruk av forskjellige analysemetoder. Det ble samlet inn ca. 100 prøver på matvarer som en antok var de viktigste kildene for transfettsyrer i hvert av de 13 deltakerlandene, deriblant Norge. Alle prøvene ble analysert etter samme metode på et nederlandsk laboratorium, og resultatene ble brukt til å sammenlikne innholdet av transfettsyrer i kostholdsunders $\varnothing$ kelser fra hvert land (29). Tilsvarende samarbeidsprosjekter kan være aktuelle innen ernæringsepidemiologi i de tilfeller der inntak av "nye" næringsstoffer skal undersøkes.

INFOODS er en internasjonal paraplyorganisasjon hvis formål først og fremst er å etablere lokale samarbeidsprosjekt rundt $\mathrm{i}$ verden tilsvarende EUROFOODS og å være pådriver for disse. Til nå er det etablert 12 slike samarbeidsprosjekt (30). INFOODS utgir dessuten Journal of Food Composition and Analysis (31) og flere publikasjoner som er relevante for arbeidet med matvaretabeller og databaser (32-34).

\section{AVSLUTTENDE KOMMENTARER}

"Persons who never fail, usually don't do anything, at least not compiling food composition tables"

(Elsie Widdowson, sitat fra workshop i Norwich, 1985).

Fram til starten på 1970-årene ble all næringsstoffberegning i Norge foretatt manuelt. Dette var et tidkrevende arbeid og den som regnet måtte selv plukke hver enkel stoffverdi fra matvaretabellen. Det hadde imidlertid noen fordeler. Kostholdsforskerne måtte i stor grad ta ansvar for de verdiene som ble benyttet, og de fikk en grunnleggende forståelse for kompleksiteten i matvaretabellen, dens svakheter og styrke og resultatene av beregningene.

Innføringen av EDB $\mathrm{i}$ arbeidet med kostholdsforskning har gitt uante muligheter til å kunne håndtere store mengder data. Økt viten om sammenhengen mellom kosthold og inntak av ulike næringsstoffer så vel som kunnskap om helsemessig betydning av "nye" kostkomponenter gjør at ønsket om å undersøke stadig flere sider av kostholdet øker. Å skaffe best mulig data for matvarenes innhold av de kostkomponenter en vil se nærmere på i en kostholdsundersøkelse bør tas med allerede i planleggingen av arbeidet.

\section{REFERANSER}

1. Greenfield H, Southgate DAT. Food composition data. Production, management and use. Elsevier, 1992.

2. Johansson L, Solvoll K, Bjørneboe G-EAa, Drevon CA. Dietary habits among Norwegian men and women. Scand J Nutr 1997; 41: 63-70.

3. Andersen LF, Nes M, Sandstad B, Bjørneboe G-EAa, Drevon CA. Dietary intake in Norwegian adolescents. Eur J Clin Nutr 1995; 49: 555-64. 
4. Andersen LF, Nes M, Bjørneboe G-EAa, Drevon CA. Food habits among 13-years-old Norwegian adolescents. Scand Jour Nutr 1997; 41: 150-4.

5. Statens ernæringsråd. Næringsmiddeltabell. Landsforeningen for kosthold og helse, Oslo, 1958.

6. Statens ernæringsråd, Statens næringsmiddeltilsyn. Matvaretabellen 1995. Universitetsforlaget, Oslo, 1995.

7. Statens ernæringsråd og Statens næringsmiddeltilsyn. Den store matvaretabellen 1995. Universitetsforlaget, Oslo, 1995.

8. Holden JM. Expert systems for the evaluation of data quality for establishing the Recommended Dietary Allowances. J Nutr 1996; 126 (9 Suppl): 2329S-36S.

9. Tabela Brasileira de Composiçao de Alimentos. http://www.usp.br/fcf/tabela.

10. Menezes EW, Caruso L, Lajolo FM. Evaluation of quality dietary fiber database. Abstract, The Third International Food Data Base Conference. Roma, 1999.

11. Nordbotten A, Løken EB, Rimestad AH. Sampling and analysis of domestically grown potatoes, vegetables and fruits. Abstract, The Third International Food Data Base Conference. Roma, 1999.

12. Statens ernæringsråd. Matvaretabell. Landsforeningen for kosthold og helse, Oslo, 1991.

13. Møller A. Levnedmiddeltabeller, 4.rev. udgave. Levnedsmiddelstyrelsen, København, 1996.

14. Livsmedelsverket. Livsmedelstabell. Livsmedelsverket, Uppsala, 1996.

15. Rastas M, Seppänen R, Knuts L-R, Hakala P, Kartilla V. Nutrient composition of foods. Kanssaneläkelaitos, Turku, 1997.

16. Solvang A, Rimestad AH. Beregning av noen sporelementer i norsk kosthold. Näringsforskning 1985; 29 (4): $139-42$.

17. FAO/WHO Expert group. Energy and protein requirements. I: FAO Nutrition Meeting Report Series No. 52. FAO/WHO, Roma, 1973.

18. Hyvönen L. New approach to fat analysis of foods. Abstract, The Second International Food Data Base Conference. Lahti, 1995.

19. Pee S, West CE, Muhilal, Karyadi D, Hautvast JG. Lack of improvement in vitamin A status with increased consumption of dark-green vegetabels. Lancet 1995; 346 (8967): 75-81.

20. Deharveng G, Charrondière UR, Slimani N, Southgate DAT, Riboli E. Comparison of nutrients in the food composition tables available in the nine European countries participating in EPIC. Eur J Clin Nutr 1999; 53: 60-79.

21. U.S. Department of Agriculture, Agricultural Research Service. USDA Nutrient Database for Standard Reference, Release 13. Nutrient Data Laboratory Home Page, http://www.nal.usda.gov/fnic/foodcomp, 1999.

22. Holland B, Welch AA, Unwin ID, Buss DH, Paul AA, Southgate DAT. McCance and Widdowson's The Composition of Foods, $5^{\text {th }}$ edition. The Royal Society of Chemistry and Ministry of Agriculture, Fisheries and Food, Cambridge, 1991.

23. Statens råd for ernæring og fysisk aktivitet. Utviklingen i norsk kosthold. Rapport nr. 1 1999. Oslo, 1999.

24. Fagerli RAa. Endringer i nordmenns matvaner på 80- og 90-tallet. Rapport nr. 1-1999. Statens institutt for forbruksforskning, Lysaker, 1999.

25. Bergstrøm L. Nutrient losses and gains in the preparation of food. Eurofoods - Enfant NLG Project. Livsmedelsverket, Uppsala, 1994.

26. Tell GS, Vollset SE, Lande B, Pedersen JI, Løken EB, Jacobsen BK. Folat og helse - ny kunnskap og nye anbefalinger. Tidsskr Nor Lageforen 1998; 118: 3155-60.

27. Almendingen K, Jordal O, Kierulf P, Sandstad B, Pedersen JI. Effects of partially hydrogenated fish oil, partially hydrogenated soybean oil, and butter on serum lipoproteins and Lp[a] in men. J Lipid Res 1995; 36: 1370-84.

28. Becker W, Borgejordet Å, Enghardt Barbieri H, Knuts L-R, Løken EB, Ovaskainen M-L, Saxholt E, Steingrimsdóttir L. Norfoods 2000 - Nordic principles for food composition data and dietary calculations. Abstract, The Third International Food Data Base Conference. Roma, 1999.

29. Hulshof KFAM, van Erp-Bart MA, Anttolainen M, Becker W, Church SM, Couet C, et al. Intake of fatty acids in Western Europe with emphasis on trans fatty acids: The TRANSFAIR study. Eur J Clin Nutr 1999; 53: $143-58$.

30. The International Network of Food Data Systems (INFOODS). http://www.fao.org/infoods/.

31. The Journal of Food Composition and Analysis. http://www.academicpress.com/jfca.

32. Klensin JC, Feskanich D, Lin V, Truswell AS, Southgate DAT. Identification of food components for INFOODS data interchange. United Nations University, Tokyo, 1989.

33. Rand WM, Pennington JAT, Murphy SP, Klensin JC. Compiling data for food composition data bases. United Nations University, Tokyo, 1991.

34. Klensin JC. INFOODS Food composition data interchange handbook. United Nations University, Tokyo, 1992. 
Appendix 1. Beregningsformler

$$
\begin{aligned}
& C V=\sum_{i=1}^{n} C V_{i} * A S_{i}(\%) / \sum_{i=1}^{n} A S_{i}(\%) \\
& C=\sum_{j=1}^{m} C V_{j} * A S_{j}(\%) / \sum_{j=1}^{m} A S_{j}(\%)
\end{aligned}
$$

$C V=$ Beregnet innhold av vitamin $\mathrm{C}$ i en potetsort. Prøver samlet fra $\mathrm{n}$ ulike dyrkingsområder.

$C V_{i}=$ Vitamin $\mathrm{C}$ innholdet i det analyserte utvalget av sorten fra regionen $i$.

$A S_{i}(\%)=$ Arealandel (\%) for potetsorten i region $i$.

$C=$ Innhold av vitamin C til bruk i matvaretabellen beregnet ut fra $m$ forskjellige potettyper.

$C V_{j}=$ Beregnet innhold av vitamin $\mathrm{C}$ i potetsorten $j$.

$A S_{j}=$ Arealandel (\%) for potetsorten $j$ i Norge.

\section{Eksempel}

I 1993 ble det tatt samleprøver av Pimpernell fra de tre viktigste dyrkingsområdene, disse ble analysert hver for seg. Veid verdi for innhold av vitamin C ble beregnet til $15 \mathrm{mg}$ per $100 \mathrm{~g}$ potet (i). Tilsvarende prøveuttak, analyser og beregninger for de to andre hovedsortene med påfølgende beregning av veid gjennomsnitt for alle tre sortene i forhold til deres markedsandeler førte til at tabellverdien for lagringspoteter ble $16 \mathrm{mg}$ (ii).

(i) $C V=\frac{13.7 * 45+12.5 * 9+17.5 * 35}{45+9+35}=15 \mathrm{mg} / 100 \mathrm{~g}$

(ii) $C=\frac{16 * 34+15 * 14+16 * 4}{34+14+4}=16 \mathrm{mg} / 100 \mathrm{~g}$ 